\title{
CALORIE DENSITY AND NUTRIENT CONTENT OF COMMONLY CONSUMED SWEETMEATS OF JASHORE DISTRICT IN BANGLADESH
}

\author{
Md. Mohsin Alam ${ }^{1}$ \\ ${ }^{1}$ Department of Nutrition and Food Technology, \\ Jashore University of Science and Technology, \\ Jashore-7408, \\ Bangladesh \\ Israt Jahan ${ }^{3}$ \\ ${ }^{3}$ Department of Public Health Nutrition, \\ Primeasia University, Banani, \\ Dhaka, \\ Bangladesh
}

\author{
Dr. A.K. Obidul Huq ${ }^{2}$ \\ ${ }^{2}$ Department of Food Technology and \\ Nutritional Science, \\ Mawlana Bhashani Science and Technology \\ University, \\ Santosh, Tangail-1902, \\ Bangladesh \\ Eyad Ahmed ${ }^{4}$ \\ ${ }^{4}$ Department of Nutrition and Food Technology, \\ Jashore University of Science and Technology, \\ Jashore-7408, \\ Bangladesh
}

Article DOI: https://doi.org/10.36713/epra4035

\footnotetext{
ABSTRACT

The purpose of the current study was to analyze the nutrient content of some commonly consumed sweetmeats of Jashore district in Bangladesh and calculation of the their calorie densities. The selected samples for the study were as follows: Rosogolla (sponge, white), Kalojam, Laddu (mewa), Chomchom (black, brown, white), Shondesh (para, chinir, cake), Doi (mishit, tok, tok-mishti). Sweetmeats were collected from three different popular shops of Jahsore Sadar in Jashore district during the period of October, 2019 to December, 2019. Proximate analysis of the samples was conducted in triplicate by various standard methods and calorie densities were calculated by amount of energy per gram of food. Ash content ranged from 2 to $5.33 \%$, moisture content ranged from 25.66 to $69.3 \%$, protein content ranged from 2.19 to $4.05 \%$, fat content ranged from 0.64 to $2.55 \%$. In case of dietary fiber, highest fiber content was found in laddu (1.37\%) and lowest fiber content was found in kalojam (0.73\%). However, carbohydrate content was measured by subtraction method and highest carbohydrate content was found in chinir sondesh (64\%) and lowest carbohydrate content was found in tok doi (22.68\%). Afterwards, Sweets were ranked in descending order according to their calorie densities. It was seen that chinir sondesh was the most calorie densed foods and tok doi was the least amongst the studied samples.

KEYWORDS: Calorie density, nutrient, sweetmeats, Jashore, Bangladesh.
} 


\section{INTRODUCTION}

The word 'Sweetmeat' means a food which is rich in sugar with milk. Everyone loves to eat sweets. The same picture is obvious in in Bangladesh also. Bangladeshis like to eat milk made sweets [1]. The sweetmeats are enjoyable, wholesome, nutritious and very popular item in Bangladesh [2]. Occasions and sweetmeats are the two intimate part of Bengali tradition as Bangladeshi people are fond of sweetmeats a lot. In this country people could not imagine to rejoice any opportune events without sweetmeats. Bangladeshi sweetmeats also renowned all over the world. In any kind of entertainment, either at household or national level, sweetmeats are a must to have [3]. There have been a variety of sweetmeats produced and also available in the markets of Bangladesh such as Rosogolla, Rasomalai, Doi, Chomchom, Kalojam, Malaikari, Sondesh, Rasokadam, Kachagolla, Peda, Rajvog, Amirti, Chanar, Polao, Monda etc.

The food market is continuously changing which leads to a growing diversity of available foods [4]. Among these varieties of foods, sweetmeats and other sweet products are mentionable. It was observed in a government study that about $10 \%$ of the total milk produced in Bangladesh are used for the preparation of chhana and finally for sweetmeat making [5] and about $4 \%$ of the milk is used for Yoghurt preparation [6]. Not only they are palatable but also supply essential nutrients like Proteins, Vitamin-B, Calcium and Phosphorus along with numerous other essential major and minor substances [7].

Information of the nutrient content of all kinds of foods is crucial for nutritional research and various applied nutrition projects, including the interpretation of food consumption studies, the nutritional assessment of food supplies, and the planning of nutritionally adequate diets. Food composition databases (FCDBs) are essential tools in these regard. In dietary treatment of diseases, knowledge of food intake and its chemical composition is essential [8]. FCDBs need to be of high quality, reliable, up-to-date and representative of the foods consumed by the population $[4,9]$. There have been some recently published FCDBs for Bangladeshi foods $[10,11]$ but none of those included commonly consumed sweetmeats of Bangladesh. Hence, the objective of the current study was to explore the nutrient content of some commonly consumed sweetmeats of Jashore district in Bangladesh and to calculate their calorie density.

\section{METHODOLGY Sample Selection}

A short market survey was conducted prior to selection of the samples. Findings from the market survey suggested to finally short listed the selected samples for the study. Thirteen samples of different varieties were selected. They were as follows: Rosogolla (sponge, white), Kalojam, Laddu (mewa), Chomchom (black, brown, white), Shondesh (para, chinir, cake), Doi (mishit, tok, tok-mishti).

\section{Sampling Area and Sample Collection}

Samples were collected from three locally popular sweet shops of Jashore sadar in Jashore district. Samples were collected in air tight bags immediately followed by bringing the samples in the Food Analysis Laboratory of Jashore University of Science and Technology. Samples of same varieties were homogenized at first and then taken for further analysis.

\section{Proximate Analysis}

The proximate analysis of was conducted by using standard methods [12]. Each samples were analyzed in triplicate.

\section{Moisture}

Samples were analyzed for moisture content in a dry air oven at $105^{\circ} \mathrm{C}$. Following formula was used: Moisture content $(\%)=[$ Final weight (in gram) $/$ Raw sample weight (in gram)] 100

Here, Final weight $=($ Crucible + dried sample)(Crucible+ Raw sample)

\section{Ash (total minerals)}

Ash content was measured by using a muffle furnace. Following formula was used:

Ash content $(\%)=[$ Final weight $($ in gram $) /$ Raw sample weight (in gram) $\times 100$

Here, Final weight $=[($ Crucible + ash $)-$ Empty crucible $]$; Raw sample weight $=[($ Crucible + Raw sample $)-$ Empty crucible]

\section{Protein}

Protein content of the samples was estimated by microkjeldahl method. The following formulas were used:

Nitrogen $(\%)=[(\mathrm{S}-\mathrm{B}) \times \mathrm{N} \times 14 \times 100] /($ Raw sample weight $\times 1000$ )

Crude protein $(\%)=$ Nitrogen $(\%) \times 6.25[13]$

Here, $\mathrm{S}=$ Titration reading for sample; $\mathrm{B}=$ Titration Reading for blank, $\mathrm{N}=$ Strength of acid.

Fat

The crude lipid content was estimated by using Soxhlet organic extraction apparatus [14]. The samples were dried prior to the extraction with petroleum ether.

Following formula was used: Crude lipid (\%) $=[(\mathrm{A}-\mathrm{B}) /$ $\mathrm{W}] \times 100$

Here, $\mathrm{A}=$ Conical flask weight + extracted oil; $\mathrm{B}=$ Conical flaks weight; $\mathrm{W}=$ Sample weight

Total Dietary Fiber (TDF)

Modified-Prosky method [12, 15] was used to measure total dietary fiber. Following formula was used: 
TDF $(\%)=[\{\mathrm{R}-(\mathrm{A}+\mathrm{P}+\mathrm{B})\} /$ Sample weight $(\mathrm{mg})] \mathrm{x} 100$ Here, $\mathrm{R}=$ Average residue weight $(\mathrm{mg}) ; \mathrm{A}=$ Average ash weight (mg); $\mathrm{P}=$ Average protein weight $(\mathrm{mg}) ; \mathrm{B}=$ Blank weight

\section{Carbohydrate}

Carbohydrate content was measured by the difference [16]. It was calculated by following equation:

Carbohydrate $(\%)=100-[$ Moisture $(\%)+$ Ash $(\%)+$ Crude protein (\%)+ Crude lipid (\%)].

\section{Calorie Density}

Calorie density was estimated by amount of energy per gram of food and foods were ranked in descending order according to their calorie densities thereafter.

\section{RESULTS AND DISCUSSION}

Table 1 shows the nutrient content of the selected sweetmeats. Para sondesh contained about $2.67 \%$ ash, $34.6 \%$ moisture, $3.87 \%$ protein, $2.15 \%$ fat, $0.77 \% \mathrm{DF}$ and $55.95 \% \mathrm{CHO}$; Para sondesh contained about $4 \%$ ash, $39.13 \%$ moisture, $4.05 \%$ protein, $2.07 \%$ fat, $0.92 \%$ DF and 50.75\% CHO; Chinir sondesh contained about 3.67\% ash, 25.66\% moisture, 3.43\% protein, $1.99 \%$ fat, $0.78 \% \mathrm{DF}$ and $64.47 \% \mathrm{CHO}$; Black chomchom contained about 5.33\% ash, 44.18\% moisture, $4.05 \%$ protein, $1.62 \%$ fat, $0.88 \%$ DF and 43.93\% CHO; Brown chomchom contained about 4\% ash, $40.1 \%$ moisture, $3.38 \%$ protein, $1.26 \%$ fat, $0.96 \%$ DF and 50.29\% CHO; White chomchom contained about $3.67 \%$ ash, 32.8\% moisture, 3.71\% protein, $1.58 \%$ fat, $1.13 \%$ DF and $57.12 \%$ CHO; Rosogolla contained about $2 \%$ ash, $34.67 \%$ moisture, $2.32 \%$ protein, $0.73 \%$ fat, $0.90 \%$ DF and $59.38 \%$ CHO; Sponge rosogolla contained about $2.67 \%$ ash, $45.47 \%$ moisture, $2.5 \%$ protein, $0.64 \%$ fat, $1.12 \%$ DF and 47.61\% CHO; Kalojam contained about 2\% ash, 35.2\% moisture, $2.19 \%$ protein, $1.42 \%$ fat, $0.73 \%$ DF and $58.46 \%$ CHO; Laddu contained about 3.33\% ash, $50.53 \%$ moisture, $2.36 \%$ protein, $1.32 \%$ fat, $1.37 \%$ DF and $41.09 \% \mathrm{CHO}$; Tok doi contained about $2 \%$ ash, $69.27 \%$ moisture, $2.74 \%$ protein, $2.29 \%$ fat, $1.03 \% \mathrm{DF}$ and $22.68 \%$ CHO; Tok misti doi contained about $2 \%$ ash, $53.17 \%$ moisture, $3.8 \%$ protein, $2.06 \%$ fat, $1.17 \%$ $\mathrm{DF}$ and 37.81\% CHO; Misti doi contained about 2\% ash, $46.2 \%$ moisture, $3.63 \%$ protein, $2.55 \%$ fat, $0.95 \%$ DF and $44.87 \%$ CHO.

\begin{tabular}{|c|c|c|c|c|c|c|}
\hline Name of sweets & $\begin{array}{c}\text { Ash } \\
\text { (g/100g) }\end{array}$ & $\begin{array}{l}\text { Moisture } \\
\text { (g/100g) }\end{array}$ & $\begin{array}{c}\text { Protein } \\
(\mathrm{g} / \mathbf{1 0 0 g})\end{array}$ & $\begin{array}{c}\text { Fat } \\
(\mathrm{g} / 100 \mathrm{~g})\end{array}$ & $\begin{array}{c}\text { DF } \\
(\mathrm{g} / \mathbf{1 0 0 g})\end{array}$ & $\begin{array}{c}\text { CHO } \\
\text { (g/100g) }\end{array}$ \\
\hline $\begin{array}{l}\text { Para sondesh } \\
\text { (mean } \pm \text { SD) }\end{array}$ & $2.67 \pm 1.15$ & $34.6 \pm 9.89$ & $3.87 \pm 0.95$ & $2.15 \pm 0.55$ & $0.77 \pm 0.12$ & $55.95 \pm 9.10$ \\
\hline $\begin{array}{l}\text { Cake sondesh } \\
\text { (mean } \pm \text { SD) }\end{array}$ & $4 \pm 0$ & $39.13 \pm 6.40$ & $4.05 \pm 0.58$ & $2.07 \pm 0.86$ & $0.92 \pm 0.38$ & $50.75 \pm 6.80$ \\
\hline $\begin{array}{l}\text { Chinir sondesh } \\
\text { (mean } \pm \text { SD) }\end{array}$ & $3.67 \pm 2.52$ & $25.66 \pm 2.09$ & $3.43 \pm 1$ & $1.99 \pm 0.69$ & $0.78 \pm 0.12$ & $64.47 \pm 4.43$ \\
\hline $\begin{array}{c}\text { Black chomchom } \\
\text { (mean } \pm \text { SD) }\end{array}$ & $5.33 \pm 1.15$ & $44.18 \pm 12.49$ & $4.05 \pm 0.77$ & $1.62 \pm 0.14$ & $0.88 \pm 0.35$ & $43.93 \pm 10.99$ \\
\hline $\begin{array}{l}\text { Brown chomchom } \\
\text { (mean } \pm \text { SD) }\end{array}$ & $4 \pm 2$ & $40.1 \pm 4.66$ & $3.38 \pm 0.53$ & $1.26 \pm 0.07$ & $0.96 \pm 0.21$ & $50.29 \pm 5.61$ \\
\hline $\begin{array}{l}\text { White chomchom } \\
\text { (mean } \pm \text { SD) }\end{array}$ & $3.67 \pm 0.58$ & $32.8 \pm 11.56$ & $3.71 \pm 0.58$ & $1.58 \pm 0.21$ & $1.13 \pm 0.56$ & $57.12 \pm 11.44$ \\
\hline $\begin{array}{c}\text { Rosogolla } \\
\text { (mean } \pm \text { SD) }\end{array}$ & $2 \pm 0$ & $34.67 \pm 6.50$ & $2.32 \pm 0.18$ & $0.73 \pm 0.07$ & $0.9 \pm 0.22$ & $59.38 \pm 6.74$ \\
\hline $\begin{array}{c}\text { Sponge rosogolla } \\
\text { (mean } \pm \text { SD) }\end{array}$ & $2.67 \pm 1.15$ & $45.47 \pm 2.89$ & $2.5 \pm 0.18$ & $0.64 \pm 0.33$ & $1.12 \pm 0.19$ & $47.61 \pm 3.20$ \\
\hline $\begin{array}{c}\text { Kalojam } \\
(\text { mean } \pm \text { SD })\end{array}$ & $2 \pm 0$ & $35.2 \pm 5.70$ & $2.19 \pm 0.72$ & $1.42 \pm 0.32$ & $0.73 \pm 0.08$ & $58.46 \pm 5.83$ \\
\hline $\begin{array}{c}\text { Laddu } \\
(\text { mean } \pm \text { SD) }\end{array}$ & $3.33 \pm 1.15$ & $50.53 \pm 7.56$ & $2.36 \pm 0.42$ & $1.32 \pm 0.44$ & $1.37 \pm 0.14$ & $41.09 \pm 8.56$ \\
\hline $\begin{array}{c}\text { Tok doi } \\
\text { (mean } \pm \text { SD) }\end{array}$ & $2 \pm 2$ & $69.27 \pm 10.86$ & $2.74 \pm 0.51$ & $2.29 \pm 0.4$ & $1.03 \pm 0.26$ & $22.68 \pm 11.06$ \\
\hline $\begin{array}{l}\text { Tok misti doi } \\
\text { (mean } \pm \text { SD) }\end{array}$ & $2 \pm 0$ & $53.17 \pm 8.26$ & $3.8 \pm 0.72$ & $2.06 \pm 0.72$ & $1.17 \pm 0.38$ & $37.81 \pm 9.73$ \\
\hline $\begin{array}{c}\text { Misti doi } \\
\text { (mean } \pm \text { SD) }\end{array}$ & $2 \pm 0$ & $46 \pm 2.163$ & $3.63 \pm 1.19$ & $2.55 \pm 0.21$ & $0.95 \pm 0.13$ & $44.87 \pm 1.67$ \\
\hline
\end{tabular}

N.B.: g=gram, $\mathrm{DF}=$ dietary fiber, $\mathrm{CHO}=$ carbohydrate, $\mathrm{SD}=$ standard deviation. 
Figure $1 \mathrm{a}$ and $1 \mathrm{~b}$ depicts the ash and moisture content of the selected samples. Ash content of the sweets ranged from 2.0 to $5.33 \mathrm{~g} / 100 \mathrm{~g}$. About $2 \mathrm{~g}$ ash was found in rosogolla, kalojam, tok doi, tok misti doi and misti doi. Highest ash content was found in black chomchom. On the other hand, cake sodesh and black chomchom contained about $4 \mathrm{~g}$ ash per $100 \mathrm{~g}$. In case of moisture content, highest moisture content was found in tokdoi $(69 \%)$ and lowest moisture content was found in chinir sondesh (25\%).

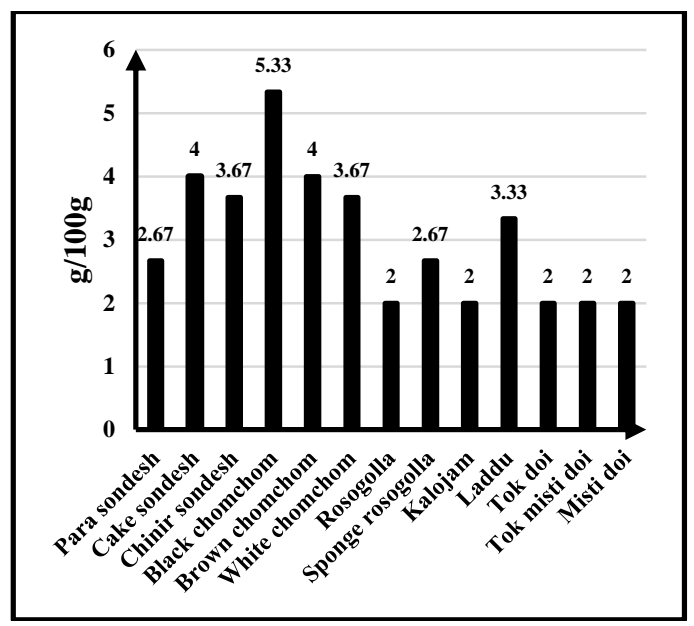

Figure 1a: Ash content of the selected samples.

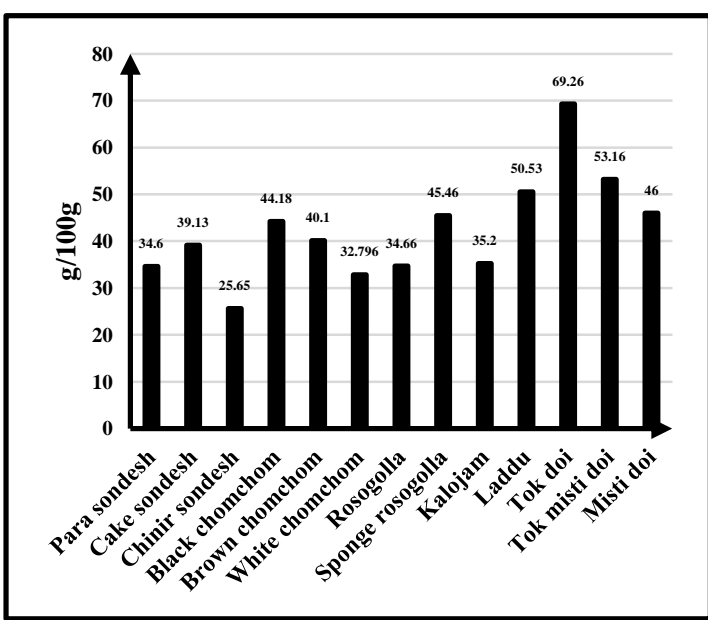

Figure 1b: Moisture content of the selected samples.
Figure $2 \mathrm{a}$ and $2 \mathrm{~b}$ depicts the protein and fat content of the selected samples. Protein content of the sweets ranged from 2.19 to $4.05 \mathrm{~g} / 100 \mathrm{~g}$. About $3.43 \mathrm{~g}$ protein was found in chinir sondesh, $2.32 \mathrm{~g}$ ash in rosogolla. Highest protein content was found in black chomchom. On the other hand, tok misti doi contained about $2.73 \mathrm{~g}$ protein per $100 \mathrm{~g}$. In case of fat content, highest fat content was found in misti doi $(2.55 \%)$ and lowest fat content was found in sponge rosogolla $(0.64 \%)$.

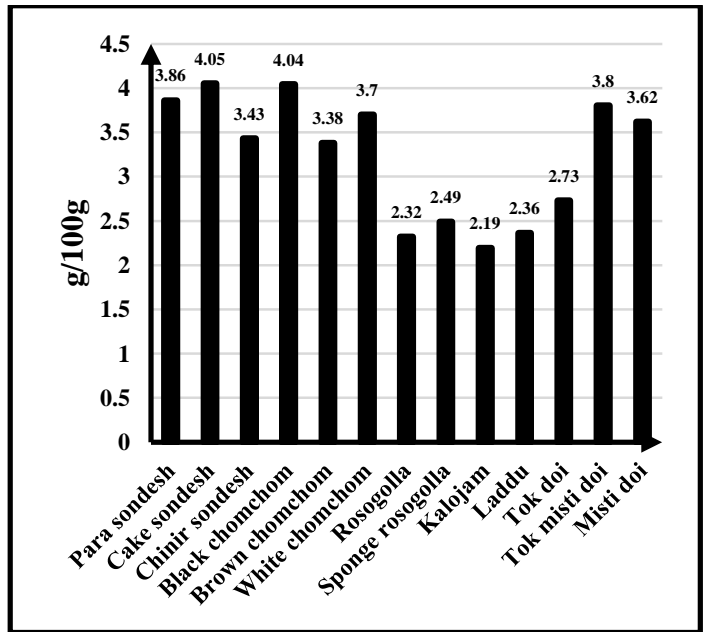

Figure 2a: Protein content of the selected sample

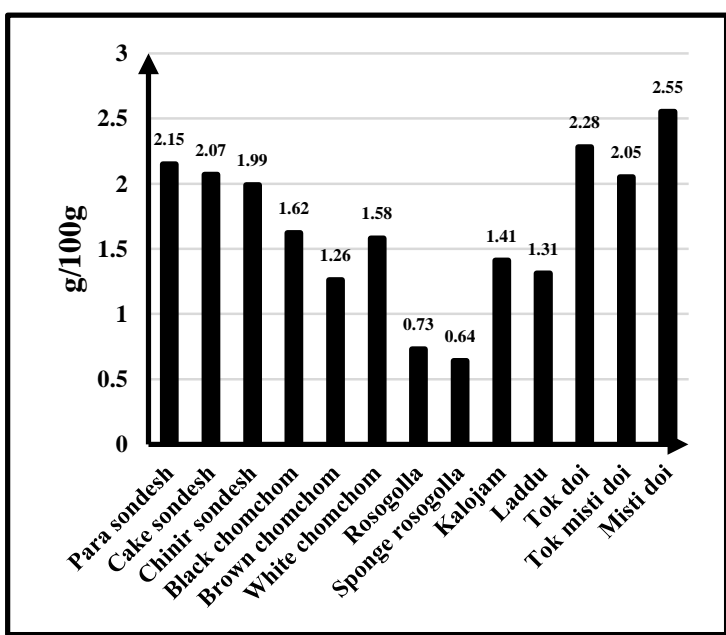

Figure 2b: Fat content of the selected samples.
Figure $3 \mathrm{a}$ and $3 \mathrm{~b}$ depicts the total dietary fiber and carbohydrate content of the selected samples. Dietary fiber content of the sweets ranged from 0.73 to $1.36 \mathrm{~g} / 100 \mathrm{~g}$. About $0.78 \mathrm{~g}$ fiber was found in chinir sondesh, $0.9 \mathrm{~g}$ fiber in rosogolla. Highest fiber content was found in laddu. On the other hand, tok misti doi contained about $1.03 \mathrm{~g}$ fiber per $100 \mathrm{~g}$. In case of carbohydrate content, highest carbohydrate content was 


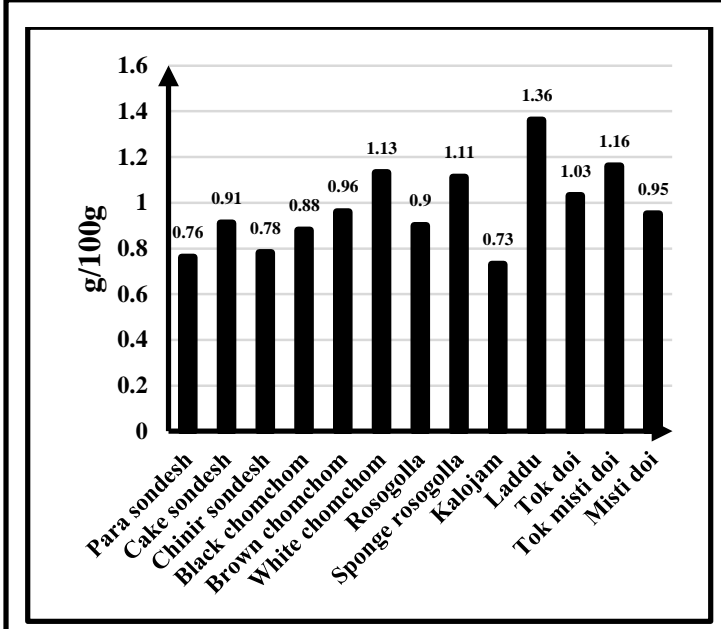

Figure 3a: Dietary fiber content of the selected samples.

Table 2 demonstrates the calorie densities of the sweets studied. It was seen that energy content of the sweets ranged from $122.23 \mathrm{kcal}$ to $289.52 \mathrm{kcal}$ per 100 $\mathrm{g}$ of sweets. Subsequently, calorie densities were calculated and ranked in descending order. After

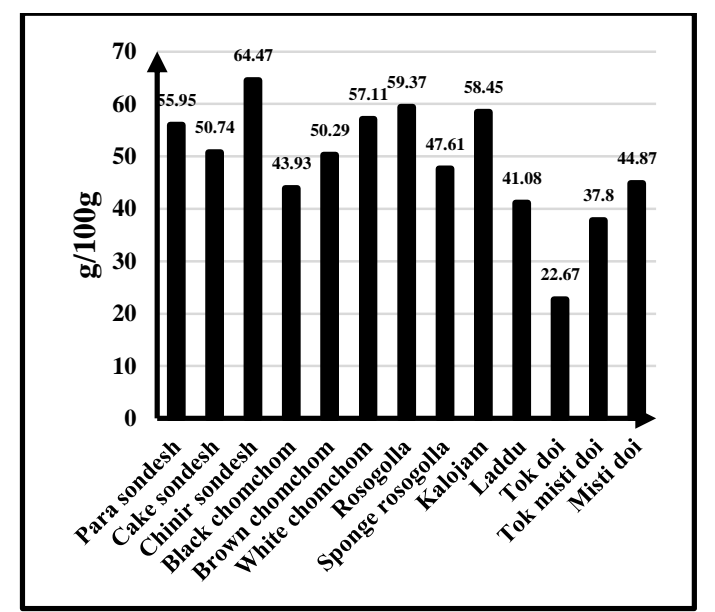

Figure 3b: Carbohydrate content of the selected samples.

ranking, it was observed that, chinir sondesh made to the top of the list since its calorie density was 2.90 (highest among the samples) and tok doi occupied the bottom of the list and ranked last amongst the samples (1.22).

Table 2: Calorie densities of the selected sweets

\begin{tabular}{|c|c|c|c|}
\hline Name of sweets & Kcal per 100 g & Calorie density & Ranking \\
\hline Para sondesh & 258.62 & 2.59 & 2 \\
\hline Cake sondesh & 237.82 & 2.38 & 6 \\
\hline Chinir sondesh & 289.52 & 2.90 & 1 \\
\hline Black chomchom & 206.5 & 2.07 & 7 \\
\hline Brown chomchom & 226.06 & 2.26 & 3 \\
\hline White chomchom & 257.51 & 2.58 & 5 \\
\hline Rosogolla & 253.4 & 2.53 & 10 \\
\hline Sponge rosogolla & 206.2 & 2.06 & 4 \\
\hline Kalojam & 255.35 & 2.55 & 11 \\
\hline Laddu & 185.65 & 1.86 & 13 \\
\hline Tok doi & 122.23 & 1.22 & 12 \\
\hline Tok misti doi & 184.95 & 1.85 & 8 \\
\hline Misti doi & 216.95 & 2.17 & \\
\hline
\end{tabular}

N.B.: Kcal= kilocalorie, g=gram. 


\section{CONCLUSION}

This study was the first of its kind in Bangladesh to reveal the calorie density and nutrient content of different varieties of commonly consumed sweetmeats of Bangladesh. Although the nutrient content and calorie densities obtained from this study may not be regarded as conclusive since these may vary due to variations in recipes and qualities may vary from place to place but the results might be useful for dietary analysis for the determination of nutrient intake in various nutrition surveys and research along with decision making in the formulation of a more cautious and insightful healthy diet plan.

\section{REFERENCES}

1. Islam MS, Basak S. Study on Sweetmeat Processing in Bangladesh. The Int. J. Eng. Sci. 2013;2:46-54.

2. Mannan, A.K.M., Hossain M.S. and Islam. M.N. 1994. Standard and Standardization of Sweetmeats. Standard of Traditional Made Chhana and Rasogolla. BAU. Res. Prog., 8: 410-413.

3. Kuila RK, Sen DC. Milk sweets of Eastern India. Milk sweets of Eastern India.. 2000:64-73.

4. SICHERT-HELLERT, W. et al. German food composition database for dietary evaluations in children and adolescents. Journal of Food Composition and Analysis, v. 20, p. 63-70, 2007. http://dx.doi. org/10.1016/j.jfca.2006.05.004

5. Forth Plan Study, No. 3. (1968). Estimation of livestock and poultry population and their products.Government of East Pakistan.Dept.Agril. Sec. P. 34.

6. Mustafa MM. A study on the preparation of fruit dahi (yoghurt). A MS Thesis. Dept. of Dairy Sci, Mymensingh Agricultural University, Mymensingh. Bangladesh. 1997.

7. Karthikeyan N, Dhanakakshmi B. Hygienic quality of Indian sweet milk products from different sources. Bangladesh Journal of Microbiology. 2010;27(2):32-7.

8. McCance and Widdowson's. 1991. The Composition of Foods, 5th ed. Royal Society of Chemistry, Cam-bridge, UK.

9. PENNINGTON, J. A. T. Applications of food composition data: Data sources and considerations for use. Journal of Food Composition and Analysis, v. 21, n. 1, p. S3-S12, 2008.

10. Shaheen N, Bari L, Mannan MA. Food composition table for Bangladesh, 2013.

11. Islam SN, Khan MN, Akhtaruzzaman M. A food composition database for Bangladesh with special reference to selected ethnic foods. Dhaka: Institute of Nutrition and Food Sciences. University of Dhaka. 2010 Nov.).

12. AOAC. Official Methods of Analysis. 18th edn. Association of Official Analytical Chemists; Arlington, VA, USA: 2005.
13. Jones DB. Factors for Converting Percentages of Nitrogen in Foods and Feeds into Percentages of Protein. US Dept. of Agrie, Cir. No. 83, 22 pp. SI. Rev. 1941.

14. Raghuramulu, N., Nair, M.K. \& Kalyanasundaram S. (2003). A manual of laboratory techniques. National Institute of Nutrition, ICMR, JamaiOsmania, Hyderabad, India.

15. Prosky, L., Asp, N-G., Furda, I., DeVries. J. W., Schweizer, T. F. \& Harland, B. F. (1985). J. AOAC Int., 68, 677-679.

16. Rand WM, Pennington JA, Murphy SP, Klensin JC. Compiling data for food composition data bases. Tokyo, Japan:: United Nations University Press; 1991. 